\title{
Current photocatalytic applications of nano-scaled titanium dioxide in the new era of "smart" technologies
}

\section{Ionela Cristina Nica, Miruna Silvia Stan ${ }^{\bowtie}$, Anca Dinischiotu}

Department of Biochemistry and Molecular Biology, Faculty of Biology, University of Bucharest, 91-95 Splaiul Independentei, 050095 Bucharest, Romania

${ }^{\square}$ Correspondence to: Miruna Silvia Stan, Department of Biochemistry and Molecular Biology, Faculty of Biology, University of Bucharest, 91-95 Splaiul Independentei, 050095 Bucharest, Romania E-mail: miruna.stan@ bio.unibuc.ro

Received: 2 March 2018 / Revised: 17 July 2018 / Accepted: 13 August 2018 / Available online: 22 August 2018

Abstract Over the past decades, nanotechnology has increasingly developed and reached to monopolize almost all of the human activity areas. Materials with nanoscaled dimensions are not only developed for technological or medical purposes, but also, they can be found in daily commercial products. So, nanoparticles' applications found a welldefined place in our modern life. Almost $70 \%$ of global pigment production is based on titanium dioxide $\left(\mathrm{TiO}_{2}\right)$, which represents also one of the top five nanoparticles used in consumer products. $\mathrm{TiO}_{2}$ surrounds our lives, being always present whether we want to take care of our health, wash our teeth or protect ourselves from harmful ultraviolet (UV) radiation. Moreover, $\mathrm{TiO}_{2}$ is commonly used as a white pigment in different inks, paints, varnishes, plastics, papers, cosmetic products, also being the most common food additive (E171). But, the main perspectives of $\mathrm{TiO}_{2}$ nanoparticles are related to different photo-induced phenomena, leading to the complete mineralization of pathogens and toxic non-biodegradable compounds, with low costs and high efficiency. Here, the authors aimed to present a brief review mainly focused on the ability of $\mathrm{TiO}_{2}$ to create surfaces with self-cleaning, anti-fogging and antibacterial properties, as well as on the current photocatalytic applications of $\mathrm{TiO}_{2}$ in new medical sanitizing techniques and biomedical devices development, wastewater management and air purification, energy and hydrogen production, and for obtaining "smart" clothes.

Keywords: titanium dioxide, photocatalysis, self-cleaning

\section{Introduction}

Manufactured nanomaterials (MNMs) are increasingly used as they have many unique and improved properties compared to conventional materials. Different products are already available on the market, ranging from nanocomposites used for car and aircraft construction, cosmetics, textiles or food packaging to medical applications (imaging techniques and nano-carrier pharmacological compounds). Nanoparticles' applications are widespread in all aspects of modern life, but photocatalysis received particular attention due to its capacity to convert solar energy with low costs and high efficiency (Wang et al., 2015; Fujishima et al., 2007). Furthermore, on the surfaces coated with a thin layer of photocatalyst, inactivation of microorganisms and mineralization of organic matter was noticed following advanced oxidation processes (AOPs) (Bogdan et al., 2015).

The photodegradation mechanism is a global research topic because photocatalytic mineralization is a complex process in which most of the involved chemical species are difficult to distinguish as a consequence of their very short lifetimes (Shi et al., 2013).

Titanium dioxide $\left(\mathrm{TiO}_{2}\right)$ is one of the most studied models for the photocatalytic process because it has ideal chemical properties, also being cheaper than other photocatalysts. A major disadvantage of $\mathrm{TiO}_{2}$ is the limited absorption of radiation, only in the UV region of the solar spectrum $(<400 \mathrm{~nm})$ (Tryba 2008). For this reason, many researchers have successfully doped $\mathrm{TiO}_{2}$ nanoparticles (NPs) with other metals $(\mathrm{Cu}, \mathrm{Fe})$ or nonmetals $(\mathrm{C}, \mathrm{N})$ to extend their photocatalytic activity in visible light, and thus enhancing the efficiency of contaminant agents' degradation (Nica et al., 2016).

What is already known regarding MNMs toxicity is that the same properties that make them both fascinating and useful are also a cause of serious concern. The effects generated by $\mathrm{TiO}_{2}$ NPs in mammalian systems are well correlated with their physicochemical properties, such as the size, shape and crystal phase (Wang and Fan 2014). 
The main issue is that these nanomaterials are redox active and has small sizes, allowing them to be internalized through the cell membranes and to generate oxidative stress (Gurr et al., 2005). According to the scientific literature, the nanomaterials diversity is huge and moreover, their synthesis approaches are in continuous development, thanks to the efforts made to design new nanomaterials with improved properties. But the technological progress should be accompanied by a constant need to check whether these properties are safe for the environment safety and human health.

\section{Titanium dioxide nanoparticles}

Titanium dioxide started to gain interest in the second part of the 20th century, with the discovery of its photocatalytic activity induced by UV radiation (Hashimoto et al., 2005). Although the first who observed the photocatalytic oxidation capacity of $\mathrm{TiO}_{2}$ was Kato, in 1964, (Kato and Masuo 1964) the event that propelled $\mathrm{TiO}_{2}$ in this field of photocatalysis was the discovery of the "Fujishima-Honda effect" (Fujishima and Honda 1972). Photo-electrolysis of water in the presence of $\mathrm{TiO}_{2}$ was initially described in Japanese (Fujishima et al., 1969), and three years later their findings were reported in English, making them accessible to the whole world.

A brief analysis of the global market of mostly used inorganic substances in the form of fine particles and nanoparticles in the new era of "smart" technologies reveals the presence of titanium dioxide $\left(\mathrm{TiO}_{2}\right)$. With a market size estimated at 13.3 billion USD in 2015 and per capita consumption of $\mathrm{TiO}_{2}$ in Europe of about 2.7 $\mathrm{kg}$, it is anticipated a progressive growth in the next years according to the report of "Titanium Dioxide $\left(\mathrm{TiO}_{2}\right)$ Market Analysis by Application - 2014 - 2025" published at the end of 2017.

\section{Physicochemical properties of titanium dioxide}

Titanium dioxide is a semiconductor material of the transition metal oxides family (Gupta and Tripathi 2011) and appears as a white, odorless and non-combustible powder characterized by a molecular weight of 79.9 $\mathrm{g} / \mathrm{mol}$ and a relative density of $4.26 \mathrm{~g} / \mathrm{cm}^{3}$ (Shi et al., 2013). The melting point of titanium dioxide is recorded at $1855^{\circ} \mathrm{C}\left(\mathrm{O}^{\prime} \mathrm{Neil} 2013\right)$, while boiling temperature may vary between 2500 and $3000{ }^{\circ} \mathrm{C}$ (Weast 1988-1989). $\mathrm{TiO}_{2}$ can be naturally found in three different crystalline forms: rutile, anatase and brookite (Le Guyader and Chen 2012). But besides these, there are also less common crystalline structures such as columbite, baddeleyite ( $\mathrm{Zhu}$ and Gao 2014), monoclinic ( $\mathrm{Wu}$ and $\mathrm{Xu}$ 2005), hollandite (Pérez-Flores et al., 2014) or ramsdellite (Kuhn et al., 2001) $\mathrm{TiO}_{2}$ types, which occur only under very special conditions (Banerjee 2011).

Rutile, with a tetragonal structure, is the most stable $\mathrm{TiO}_{2}$ crystal form, even at high temperatures and pressure values up to $60 \mathrm{kbar}$, where columbite becomes the thermodynamically favorable phase (Chen and Mao 2007). Its name is derived from the Latin word rutilus, which means "red", due to a deep red light that was observed to be transmitted by some minerals (Carp et al., 2004).

Anatase crystals also have a tetragonal structure, but $\mathrm{TiO}_{6}$ octahedron is a little more distorted than rutile; in 1801, R.J. Hauy named this form based on the Greek word anatasis which means "extension" due to its elongated vertical axis (Spencer 1911). The anatase phase of $\mathrm{TiO}_{2}$ has many photocatalytic applications and is also the most chemically reactive because of the lower oxygen adsorption capacity and the higher degree of hydroxylation (Xia et al., 2013).

Brookite, discovered by Armand Lévy and named in honor of the mineralogist Henry James Brooke (Lévy 1825), is characterized by an orthorhombic structure, more complicated and less dense than rutile or anatase, with a larger volume (Thompson and Yates 2006), but is rarely used experimentally. Usually, $\mathrm{TiO}_{2}$ nanoparticles used in research contain an anatase-rutile mixture.

One of the unique features of $\mathrm{TiO}_{2}$-based nanomaterials is that they possess two photo-induced properties: photocatalytic activity (Fig. 1) and superhydrophilicity/ superhydrophobicity (Lai et al., 2016). The term "photocatalysis" can be defined as an acceleration of a photoreaction in the presence of a catalyst (Castellote and Bengtsson 2011). Photocatalysts are materials that can absorb energy from exposure to electromagnetic radiation, more precisely from photons with an amount of energy equal or higher than the size of their band gap, which in case of $\mathrm{TiO}_{2}$ is almost $3.2 \mathrm{eV}$. Following the energy leap of an electron from the valence band (lower energy) to the conduction band (higher energy) in the photocatalyst structure, an electron-hole pair is formed (Carcel 2011).

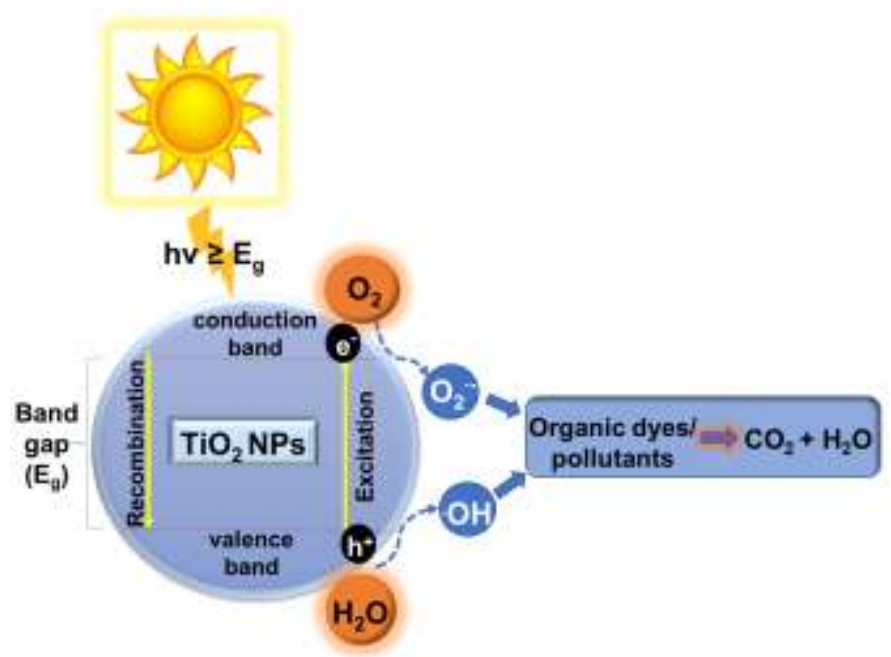

Fig. 1. The photocatalytic mechanism of $\mathrm{TiO}_{2}$ nanoparticles. 


\section{Limits of exposure to titanium dioxide}

Titanium is also found in biological systems, but only in very small quantities, as it is not an essential element for humans or animals. The concentration of titanium-based compounds in drinking water is generally low, and a typical diet can make a daily contribution of only 300$400 \mu \mathrm{g}$ (Shi et al., 2013).

Food and Drug Administration Agency of the United States (FDA) approved $\mathrm{TiO}_{2}$ as a food coloring additive with the requirement that the additive "does not exceed $1 \%$ of body weight (b.w.)". $\mathrm{TiO}_{2}$ has also been approved by the FDA as a "food contact substance" in food packaging (FDA 2002). Taking into account the differences in physicochemical properties and the toxic effects of $\mathrm{TiO}_{2}$ fine particles and nanoparticles, it is necessary to be established a specific exposure limit for these kinds of materials.

According to EU recommendation from October 2011, a "nanomaterial" is "a natural, incidental or manufactured material containing particles, in an unbound state or as an aggregate or as an agglomerate and where, for $50 \%$ or more of the particles in the number size distribution, one or more external dimensions is in the size range $1 \mathrm{~nm}$ 100 nm" (EU Directive 2011).

$\mathrm{TiO}_{2}$ particles are synthesized and used in various fractions, including fine $(\sim 0.1-2.5 \mu \mathrm{m})$ and nano-sized $(<0.1 \mu \mathrm{m})$ particles. Human exposure to $\mathrm{TiO}_{2}$ nanoparticles may occur both during the manufacture processes and after the use of different nanoparticlebased products (Dankovic and Kuempel 2007).

American Conference of Governmental Industrial Hygienists (ACGIH) has set a threshold value of 10 $\mathrm{mg} / \mathrm{m}^{3}$ for $\mathrm{TiO}_{2}$ fine particles in a normal 8-h workday and a 40-h workweek (ACGIH 2001). Occupational Safety and Health Administration (OSHA) has established the exposure limit for fine particles of $\mathrm{TiO}_{2}$ at $15 \mathrm{mg} / \mathrm{m}^{3}$. In November 2005, National Institute for Occupational Safety and Health (NIOSH) of the USA proposed a recommended exposure limit of $0.3 \mathrm{mg} / \mathrm{m}^{3}$, which was ten times lower compared to the one set for fine particles (NIOSH 2011). New Energy and Industrial Technology Development Organization (NEDO) from Japan established an exposure concentration limit for $\mathrm{TiO}_{2}$ nanoparticles of $1.2 \mathrm{mg} / \mathrm{m}^{3}$ (Singh 2015).

\section{Current applications of $\mathrm{TiO}_{2} \mathrm{NPs}$}

Owing to its very high refractive index, $\mathrm{TiO}_{2}$ represents about $70 \%$ of the total amount of worldwide pigment production, being among the top five types of nanoparticles used in consumer products (Baan et al., 2006). Mostly, $\mathrm{TiO}_{2}$ is used as a white pigment (CI 77891) and opacifier in paints, coatings, plastics, papers, as well as in most toothpaste brands, medicines (Allam and Kumar 2011), inks (Høgsberg et al., 2011), permanent make-up colorants (Wenzel et al., 2010), sunscreens and other cosmetics. Also, $\mathrm{TiO}_{2}$ is a common food additive (E171) that is mainly found in sweets, candies and chewing gums (Weir et al., 2012).

$\mathrm{TiO}_{2}$ and zinc oxide $(\mathrm{ZnO})$ are commonly used as sunscreen agents because of their ability to absorb and scatter UV light. As $\mathrm{TiO}_{2}$ is more efficient for long wave ultraviolet $\mathrm{A}$ (UVA) and $\mathrm{ZnO}$ in the short wave ultraviolet B (UVB) range, the combination of these particles provides protection on a wider UV spectrum (Smijs and Pavel 2011). Also, the effectiveness of these UV filters increases when they are used in the nano scale (Patel et al., 2011).

Even if the penetration by nanoparticles contained in sunscreen products through the epidermal layer has not been observed so far, human skin is not an impenetrable barrier. Hair follicles and abrasions offer opportunities for particles to reach the vasculature (Huang et al., 2013). However, scanning electron microscopy has shown that titanium penetrates the skin through vacant follicles, but does not penetrate into the dermis or deep layers of the epidermis (Senzui et al., 2010).

Considering the high thermodynamic stability, as well as the photocatalytic and anticorrosive properties of $\mathrm{TiO}_{2}$ (Malhi 2012), besides the $\mathrm{TiO}_{2}$ daily uses, there is also a distinct category of applications based on photocatalysis. Therefore, the main perspectives of nano-scaled $\mathrm{TiO}_{2}$ take into account different photo-induced phenomena, such as antibacterial and self-cleaning effect, energy and hydrogen production, photo-oxidation of organic pollutants, wastewater management and air purification.

\section{Antimicrobial effect and biomedical applications of $\mathrm{TiO}_{2} \mathrm{NPS}$}

In recent years, the medical field has faced a number of serious problems caused by harmful microorganisms, including Legionella infections in full-time baths, food poisoning by Staphylococcus aureus, and hospital infections caused by drug-resistant bacteria (Yadav et al., 2016). Nowadays, the ability of different microorganisms to share genetic determinants in stressful conditions, leading to a great antimicrobial resistance, represents an important healthcare issue (Nica et al., 2016). Moreover, the increasing number of modern clinical procedures requires the use of biomedical devices. One of the major problems of both short-term devices and implantable prostheses is represented by infections associated with the bacterial proliferation and colonization (Vasilev et al., 2009). Planktonic bacteria that colonize the surface of a device tend to form a biofilm, and sessile bacterial cells, enclosed in a polymeric matrix synthesized by them, can exhibit tremendous resistance to the immune response of the host and also to antibiotics (Costerton et al., 1999). For this reason, metal nanoparticles with their bactericidal and bacteriostatic effects became very useful to current medical requirements (Ahrari et al., 2015).

$\mathrm{TiO}_{2}$ has been shown to be useful as a photocatalytic agent for killing various groups of microorganisms, such as bacteria, fungi and viruses, due to its high photoreactivity and broad-spectrum antibiosis (Gupta et 
al., 2013). In 1985, Matsunaga et al. reported for the first time the antimicrobial photocatalytic effect of $\mathrm{TiO}_{2}$ on Saccharomyces cerevisiae (yeast), Lactobacillus acidophilus and Escherichia coli (bacteria), and Chlorella vulgaris (green algae) (Matsunaga et al., 1985). The antibacterial mechanism occurs as a result of the reaction between the reactive oxygen species (ROS) and the structural bacterial components, such as the cell wall and cell membrane. The most sensitive targets for ROS attack are the unsaturated phospholipids of cell membranes, while lipid peroxidation is considered to be the lethal mechanism of action for the antibacterial photocatalytic process (Cai et al., 2013).

Sunada and his collaborators proposed a three-step mechanism for photo-killing bacteria on $\mathrm{TiO}_{2}$ coated surfaces following irradiation. According to this theory, the final step of total decomposition of bacterial toxins to $\mathrm{CO}_{2}$ and $\mathrm{H}_{2} \mathrm{O}$ makes photocatalytic sterilization the most efficient approach compared to classical antibacterial treatments (Sunada et al., 2003).

One of the main advantages of sterilization by photocatalytic oxidation is that it does not need electrical power or chemical reagents, light, oxygen and water being the only necessary ingredients. Also, $\mathrm{TiO}_{2}$ surfaces are not toxic, are safety for use and do not cause environmental pollution. These features make $\mathrm{TiO}_{2}$-based self-sterilizing materials ideal for future medical applications (Visai et al., 2011). Therefore, different approaches have been adopted to extend the photoinduced activity in visible light and remove possible electron-hole recombination, which are two major limitations for $\mathrm{TiO}_{2}$ photocatalytic applications. The cooperative action of co-doping $\mathrm{TiO}_{2}$ nanoparticles with transition metals $(\mathrm{W}, \mathrm{V}, \mathrm{Ag}$ or $\mathrm{Cu})$ and non-metals $(\mathrm{S}, \mathrm{C}$ or $\mathrm{N}$ ), as well as combining it with other semiconductors, could be the most successful strategies to prepare composites with enhanced antibacterial properties (Yuan et al., 2010).

According to Bahadur et al., $\mathrm{TiO}_{2}$ nanoparticles doped with silver (Ag) ions inactivated Escherichia coli, Pseudomonas aeruginosa, Bacillus subtilis and Staphylococcus aureus bacterial strains (Bahadur et al., 2016). Other studies suggested that copper $(\mathrm{Cu})$ might be a more effective antimicrobial agent than $\mathrm{Ag}$ due to its low cytotoxicity (Norambuena et al., 2016), Cu-doped $\mathrm{TiO}_{2}$ nanoparticles being able to inhibit the growth of Mycobacterium smegmatis (Wu et al., 2010). But, most of the studies focused on non-metal doped $\mathrm{TiO}_{2}$ nanoparticles that showed remarkable photoactivity under visible light irradiation. Cheng et al. reported the visible light activity of carbon doped $\mathrm{TiO}_{2}$ against Staphylococcus aureus, Shigella flexneri and Acinetobacter baumannii (Cheng et al., 2009). Moreover, Hamal et al. demonstrated that $\mathrm{TiO}_{2}$ nanoparticles codoped with silver, carbon and sulfur can act as a multifunctional biocide, proving strong antimicrobial properties against Escherichia coli and Bacillus subtilis spores without light activation (Hamal et al., 2010).
In the last years, nanotechnology has also expanded in the field of dentistry. Recently, the medical and dental literature paid more attention to the photocatalytic activity of $\mathrm{TiO}_{2}$ nanoparticles. It was evidenced that $\mathrm{TiO}_{2}$-containing resins exhibit significant antimicrobial effects (Arai et al., 2009), which may be very useful in preventing recurrent caries and enamel demineralization. The addition of $\mathrm{TiO}_{2}$ nanoparticles to dental composites led to the development of new materials with improved mechanical characteristics, such as modulus of elasticity, microdurity and strength (Heravi et al., 2013) and improved its antibacterial effects without any changes in physical properties (Poosti et al., 2013).

\section{Self-cleaning and anti-fogging surfaces based on $\mathrm{TiO}_{2} \mathrm{NPS}$}

Daily deposits of dirt, soot and other pollutants released by vehicles lead to a constant need of cleaning the buildings. Also, the growth of various microorganisms (bacteria, algae, fungi) disfigured facades of edifices, causing mechanical weakness and even destruction. To prevent this, constructions can be built or only covered using materials that incorporate photocatalysts. Commercial surfaces with self-cleaning properties are usually made of thin $\mathrm{TiO}_{2}$ layers whose photo-induced catalytic performances are well-known (Jesus et al., 2015).

Titanium dioxide-coated surfaces are not contaminated even in the absence of light because nanoparticles create a rough superhydrophobic structure, which removes water drops and dust particles, preventing it from wetting or soiling. This phenomenon is inspired by nature and was observed for the first time in Nelumbo nucifera leaves, being called the "lotus effect" (Yamamoto et al., 2015). In contrast to hydrophobic surfaces that are kept clean due to water-repellent structures, the hydrophilic coatings use photocatalysis to break down dirt and any other kind of impurities or contaminants under light exposure (Ganesh et al., 2011). Although photo-induced suprehydrophilia and degradation of organic contaminants are two different processes, they occur in the same time. Pollutants gradually adsorbed from a surface covered with a $\mathrm{TiO}_{2}$ film can be decomposed in the presence of light, and then removed by rain. The superhydrophilic surfaces coated with a thin layer of $\mathrm{TiO}_{2}$ NPs have the ability to attract water, forming a continuous flowing film, washing away the dust particles or other contaminants (Jin et al., 2013).

Anti-fogging coatings also rely on the photo-induced hydrophilic property of $\mathrm{TiO}_{2}$. On a superhydrophilic surface, the accumulation of small water drops leading to steaming and scattering of light is prevented, but instead, a uniform layer of water that will not disperse the light is formed (Tricoli et al., 2009).

Self-cleaning and anti-fogging properties of $\mathrm{TiO}_{2} \mathrm{NPs}$ not only remained at the research stage, they were adopted by large companies from building materials and glass 
industry and applied to the manufacture of their own products. For example, Activ ${ }^{\mathrm{TM}}$ glass developed by Pilkington is one of the most successful commercial selfcleaning products, being used in different buildings around the world (Mills et al., 2003). Hydrotech ${ }^{\mathrm{TM}}$, introduced by the Japanese company TOTO Ltd., is another photo-induced superhydrophilicity based technology (Shimohigoshi and Saeki 2007). It is very impressive that self-cleaning windows and tiles are widely used in Japan. $\mathrm{TiO}_{2} \mathrm{NPs}$ containing glass and cements have also been used on the surface of National Opera Hall from China, in Dives in Misericordia Church from Rome and on the roof of Dubai Sports City's Cricket Stadium (Banerjee et al., 2015).

\section{6. $\mathrm{TiO}_{2} \mathrm{NPs}$-treated textiles with self-cleaning properties}

Considering the important role of fabrics in human life from today's society, a new interesting research field involving both textile industry and nanotechnology has been developed over the last decades (Dastjerdi and Montazer 2010). It was found that by nano-decorating textiles with active particles, fibers properties are improved, gaining new features, such as water repellency (Bagherzadeh et al., 2007), increased mechanical strength (Davis et al., 2011), wrinkle resistance, antistatic, color change (Gorensek and Recelj 2007) or UV protection (Mondal and $\mathrm{Hu}$ 2016).

$\mathrm{TiO}_{2}$ turned out to be the most effective and cheap alternative for textile coatings (Abidi et al., 2009; Mihailović et al., 2011). Recently, many articles focused on the functionalization of textiles with $\mathrm{TiO}_{2} \mathrm{NPs}$ and their self-cleaning properties (Bozzi et al., 2005; Lee et al., 2013; Afzal et al., 2013; Pakdel et al., 2015). Accordingly, various photocatalytic fibers based on cotton (Lam et al., 2010), polyester (Pasqui and Barbucci 2014), wool (Tang et al., 2011), and silk (Li et al., 2012) were designed. But, what is gratifying is that despite the changes that might have occurred during the functionalization process, these materials remain harmless to the skin cells. For example, nano $\mathrm{TiO}_{2}$-coated fabrics exhibit a great antibacterial efficiency against Escherichia coli and Staphylococcus aureus and antifungal activity against Candida albicans, along with a significant self-cleaning capacity and no cytotoxic effects on human skin fibroblasts (Stan et al., 2016).

Self-cleaning fabrics can be obtained by applying an active photocatalytic layer containing the oxide of a transition metal. This coating reacts with organic compounds or pollutants deposited on the fabric, decomposing them under sunlight exposure to simple inorganic compounds $\left(\mathrm{CO}_{2}\right.$ and $\left.\mathrm{H}_{2} \mathrm{O}\right)$, which are subsequently removed by heat, wind or rain (Veronovski et al., 2009).

The hydrophobicity/hydrophilicity of textiles usually varies from one fabric to another, depending on the chemical composition and surface charges. Different treatments are needed to modify the physicochemical properties of the textile surface for improving the adhesion between photocatalyst and fiber, minimizing NPs losses in case of frequent washing (Kaihong et al., 2007). Another issue is about the photo-activity that $\mathrm{TiO}_{2}$ might have on textiles and fiber degradation. In this regard, Veronovski and his team developed a titaniumsilica composite shell that can be used to avoid the negative impact (Veronovski et al., 2009). However, any applied pre-treatment only modifies the outer superficial layers of the fabric without affecting its properties.

Finally, an actual application of these "smart" textiles was introduced by US Army in collaboration with the Massachusetts Institute of Technology. They have created a waterproof, lightweight and breathable uniform that has the ability to kill bacteria. Furthermore, the development of "nanopores" in soldiers' uniforms, which close when chemical or biological agents are detected, is attempted for the protection against chemical or biological weapons during wars (Karst and Yang 2006).

\section{Photocatalytic applications of $\mathrm{TiO}_{2} \mathrm{NPs}$ for air treatment and purification}

Breathing is a vital need not only for humans, but also for all aerobic forms of life on Earth, so the poor air quality is detrimental to both our health and environment. Indoor air pollution started to gain interest in the early 1990s when statistics showed that the most people spend more than $80 \%$ of the time indoors where the risk of exposure to pollutants is higher than outdoors (Le et al., 2015).

Pathogenic microorganisms spread through ventilation systems represent one of the main causes of air quality degradation inside buildings, offices or production units. Constant exposure to these contaminants can result into various health problems like irritation, systemic infections, allergies and other respiratory or skin disorders (Verdier et al., 2014). The accumulation of volatile organic compounds (VOCs) is another major pollutant in indoor environment, which induce several adverse effects on human health, including headache, excessive fatigue and skin irritations (Weon et al., 2017). Car emissions have a particular impact on global air quality. The main emissions from motor vehicles are nitrogen oxides $\left(\mathrm{NO}_{\mathrm{x}}\right)$, hydrocarbons $(\mathrm{HC})$ and carbon monoxide (CO) (Nischk et al., 2014).

High-efficiency particulate arrestance (HEPA) and electrostatic filters are primarily used to purify indoor air. A preliminary study realized by Limmongkon and his collaborators showed that an electrostatic air filter could reduce fungal (Aspergillus niger and Penicillium citrinum) and bacterial (Staphylococcus epidermidis and Bacillus subtilis) growth from initial concentrations of $34.000-80.000 \mathrm{CFU} / \mathrm{m}^{3}$ at the recommended concentration of $500 \mathrm{CFU} / \mathrm{m}^{3}$ in just $30-40$ minutes (Limmongkon et al., 2009). But besides conventional methods, it was demonstrated that photocatalytic oxidation can be an equally effective tool in removing both organic and inorganic compounds together with microorganisms from outdoor and indoor air (Binas et al., 2017). The use of an electrostatic air filter in combination 
with photocatalytic oxidation has not yet been studied, but it could be one of the most promising methods of air decontamination (Limmongkon et al., 2013). Instead, a glass fiber air filter coated with $\mathrm{TiO}_{2}$ was proposed as a cheaper alternative to HEPA filters for Mycobacterium tuberculosis removal (Thunyasirinon et al., 2015).

Photocatalysis proved its efficiency in reducing a number of air contaminants, especially in places with high levels of pollution, such as intensely circulated streets, road tunnels or urban areas. In the last years, several projects have been launched in Belgium to improve air quality by building new photocatalytic sidewalks in industrial areas from Wijnegem and Lier (Boonen and Beeldens 2014).

The extensive use of $\mathrm{TiO}_{2}$ NPs in building materials with photocatalytic properties is due to their low costs, compatibility with traditional building materials without any changes in original performance, high catalytic activity compared to other metal oxides, and efficiency even under weak solar irradiation in atmospheric environment (Chen and Poon 2009).

The European PhotoPAQ project was designed to demonstrate the usefulness of photocatalytic building materials for urban air purification purposes. Photocatalytic cement TX Active ${ }^{\circledR}$ developed by CTG Italcementi Group was applied to the side walls and the roof of one section of Leopold II tunnel from Brussels and the air purification system was activated by an UV illumination system (Gallus et al., 2015).

Since the first application of photocatalytic pavements in Antwerp (2004-2005), there has been a lot of progress in the field of photocatalysis. Newer, better and more effective materials are constantly developed, and research is increasingly focused on $\mathrm{TiO}_{2}$-based materials photoactive in visible light.

\section{Wastewater management using $\mathrm{TiO}_{2} \mathrm{NPS}$}

The exponential growth of the human population over the last decades has also led to an increasing need of drinking water supply. But, at the moment our society is facing various environmental issues including water pollution, which is a major worldwide cause of deaths. Incorrect management of water resources and the inefficiency of common chlorine-based disinfectants in water treatment are reflected in the increasing number of infectious diseases outbreaks (Bogdan et al., 2015).

The biggest threat to public health is represented by the toxic and non-biodegradable compounds that can be released into the environment through industrial wastewater (Nickheslat et al., 2013). Phenolic compounds represent the main group of wastewater pollutants produced by a wide range of industrial fields such as: chemicals, paints, textiles, pesticides, food processing, biotechnology, cosmetics, oil refineries, coal mines and cars` production, or released by natural processes (degradation of algae or vegetation) (Borji et al., 2014).

Other significant water contamination agents are the pharmaceutical products. As their variety has increased significantly over the past decades due to the rapid development of medical science, more and more antiinflammatory drugs and antibiotics have been detected in surface water and effluents of the wastewater treatment plants (Farzdakia et al., 2015).

For this reason, the recent Directive of the European Parliament updated the water framework policy (EU Directive 2013). The new EU Directive promotes preventive actions, identifying the nature of different sources of pollution, and designing innovative wastewater treatment technologies with lower costs and higher efficiency. Furthermore, it pays attention to the importance of monitoring pollutants that are not usually considered hazardous but can have toxicological implications on humans' health and environment safety (Ribeiro et al., 2015).

Treatment of wastewater containing toxic organic compounds is usually done by physicochemical methods such as adsorption, sedimentation, filtration and chemical oxidation, but conventional techniques do not completely remove the pollutants, generating harmful secondary products that are high consumers of chemical reagents and time (Dong et al., 2015). Consequently, the development of new environmentally friendly technologies capable to mineralize and remove nonbiodegradable compounds and pathogens from water became an urgent requirement (Martínez-Huitle et al., 2015).

Photocatalysis with $\mathrm{TiO}_{2} \mathrm{NPs}$ proved to be useful for the complete photodegradation of hazardous pollutants in wastewater (Morales-Torres and Pastrana- Martínez 2014). The spectrum of compounds that are sensitive to the destructive power of $\mathrm{TiO}_{2} \mathrm{NPs}$ is remarkable (Lazar et al., 2012). Even the most resistant organic compounds can be degraded by photocatalysis into harmless products $\left(\mathrm{H}_{2} \mathrm{O}\right.$ and $\left.\mathrm{CO}_{2}\right)$ (Patel et al., 2014).

$\mathrm{TiO}_{2}$ applications in water purification require the synthesis of $\mathrm{TiO}_{2}$ films on suitable substrates, reducing their surface area and, subsequently, their photocatalytic activity. Therefore, three-dimensional nanoarchitectures, such as porous $\mathrm{TiO}_{2}$ nanotubes are among the most attractive approaches due to their excellent performances (Lee et al., 2014). A novel cylindrical multi-column photocatalytic reactor (CMCPR) packed with $\mathrm{TiO}_{2^{-}}$ coated silica gel beads has been obtained and efficiently applied for the degradation of different classes of water pollutants ( $\mathrm{Li}$ et al., 2015).

\section{Energy and hydrogen production using $\mathrm{TiO}_{2} \mathrm{NPs}$}

It is extremely difficult to estimate exactly what are the remaining reserves of fossil fuels on earth and when exactly they will be exhausted, but the trend is clear and the world is heading for a major energy crisis.

Fast depletion of the natural resources and the increasing rate of environmental pollution are highly debated issues, leading to a critical need for the development of innovative clean energy resources. Hydrogen is considered the ideal candidate as an energy carrier in the 
future since it is renewable and can be easily transformed into electricity by fuel cells (Dholam et al., 2009). There are a number of attempts to find alternative ways to hydrogen gas production from solar radiation and wind power, avoiding the emission of greenhouse gases. Photocatalytic water-splitting using sunlight could be a promising solution for the environmental issues caused by hydrogen production. Photocatalytic hydrogen production is based on two essential elements: a semiconductor, absorbing the light that generates electron-hole pairs, and a metal that acts as an electron trapper or a co-catalyst (Chen et al., 2012). Among all the semiconductors with great potential for photocatalysis that have been explored so far, $\mathrm{TiO}_{2}$ still remains the most suitable material for hydrogen production, owing to its intrinsic properties (Chiarello et al., 2017). But the hydrogen production rate using $\mathrm{TiO}_{2}$ is quite low due to fast charge recombination and its capacity to use only UV light from solar spectrum (Ni et al., 2007).

In the last decades, several methods have been developed to improve the photocatalytic activity of $\mathrm{TiO}_{2}$, expanding it into visible light. Although it has been observed that noble metal deposition on its surface ( $\mathrm{Yu}$ and Jaroniec 2010), metal and nonmetal ion doping (Yoong et al., 2009), or the preparation of composite semiconductors (Xiang et al., 2012) can enhance hydrogen production, combination of different techniques is required for an increased efficiency.

For a better understanding and assumption of the photocatalytic hydrogen production mechanism, more work still needs to be done. Moreover, the development of a photo-reactor for photocatalytic water splitting in an inexpensive and environmentally friendly manner will play an essential role in developing the future hydrogen economy.

\section{Conclusions}

Realizing how essential it is to keep our planet clean, researchers are constantly working to develop new ecofriendly alternative technologies for all fields of human activity. Sustainable energy production and pollutants degradation are two of the most intensively researched areas. Titanium dioxide is a semiconductor with multiple applications that can be used as an energy catalyst (to produce hydrogen from photocatalytic water splitting), an environmental catalyst (for water and air purification) or a biomedical catalyst (in antimicrobial and self-cleaning surfaces and coatings).

In conclusion, titanium dioxide is the most suitable photocatalyst, considering its lack of biological and chemical reactivity, its strong oxidizing capacity, low toxicity, insolubility, relatively low costs, and long-term stability against photo- and chemical corrosion. Researchers` efforts for improving the photo-activity of $\mathrm{TiO}_{2}$ by modifying its surface and expanding its activity in the visible light spectrum will enable the full potential of this photocatalyst to be exploited.

\section{Acknowledgments}

This work was supported by the project NANO-BIO-INT (PNIII-P1-1.1-PD-2016-1562) funded by UEFISCDI.

(C) The Author(s) 2018

Open Access This article is distributed under the terms of the Creative Commons Attribution 4.0 International License (http://creativecommons.org/licenses/by/4.0/) which permits unrestricted use, distribution, and reproduction in any medium, provided you give appropriate credit to the original author(s) and the source, provide a link to the Creative Commons license, and indicate if changes were made.

\section{References}

Abidi N., Cabrales L., Hequet E. 2009. Functionalization of a cotton fabric surface with titania nanosols: applications for self-cleaning and UV-protection properties. ACS Appl. Mater. Interfaces 1, 2141-2146.

ACGIH 2001. Titanium dioxide. In: Documentation of the threshold limit values for chemical substances. 7th edition. Cincinnati, OH: American Conference of Governmental Industrial Hygienists.

Afzal S., Daoud W.A., Langford S.J. 2013. Photostable self-cleaning cotton by a copper (II) porphyrin/TiO2 visible-light photocatalytic system. ACS Appl. Mater. Interfaces 5, 4753-4759.

Ahrari F., Eslami N., Rajabi O., Ghazvini K., Barati S. 2015. The antimicrobial sensitivity of Streptococcus mutans and Streptococcus sangius to colloidal solutions of different nanoparticles applied as mouthwashes. Dent. Res. J. 12, 44-49.

Allam K.V., Kumar G.P. 2011. Colorants-the cosmetics for the pharmaceutical dosage forms. Int. J. Pharm. Pharm. Sci. 3, 13-21.

Arai T., Ueda T., Sugiyama T., Sakurai K. 2009. Inhibiting microbial adhesion to denture base acrylic resin by titanium dioxide coating. J. Oral Rehabil. 36, 902-908.

Baan R., Straif K., Grosse Y., Secretan B., El Ghissassi F., Cogliano V. 2006. Carcinogenicity of carbon black, titanium dioxide, and talc. Lancet Oncol. 7, 295-296.

Bagherzadeh R., Montazer M., Latifi M., Sheikhzadeh M., Sattari M. 2007. Evaluation of comfort properties of polyester knitted spacer fabrics finished with water repellent and antimicrobial agents. Fiber. Polym. 8, 386-392.

Bahadur J., Agrawal S., Panwar V., Parveen A., Pal K. 2016. Antibacterial properties of silver doped $\mathrm{TiO}_{2}$ nanoparticles synthesized via sol-gel technique. Macromol. Res. 24, 488-493.

Banerjee A.N. 2011. The design, fabrication, and photocatalytic utility of nanostructured semiconductors: focus on $\mathrm{TiO}_{2}$-based nanostructures. Nanotechnol. Sci. Appl. 4, 35-65. 
Banerjee S., Dionysiou D.D., Pillai S.C. 2015. Selfcleaning applications of $\mathrm{TiO}_{2}$ by photo-induced hydrophilicity and photocatalysis. Appl. Catal. B: Environmental 176, 396-428.

Binas V., Venieri D., Kotzias D., Kiriakidis G. 2017. Modified $\mathrm{TiO}_{2}$ based photocatalysts for improved air and health quality. J. Materiomics 3, 3-16.

Bogdan J., Jackowska-Tracz A., Zarzyńska J., PławińskaCzarnak J. 2015. Chances and limitations of nanosized titanium dioxide practical application in view of its physicochemical properties. Nanoscale Res. Lett. 10, 57-67.

Boonen E., Beeldens A. 2014. Recent photocatalytic applications for air purification in Belgium. Coatings 4, 553-573.

Borji S.H., Nasseri S., Mahvi A.H., Nabizadeh R., Javadi A.H. 2014. Investigation of photocatalytic degradation of phenol by $\mathrm{Fe}(\mathrm{III})$-doped $\mathrm{TiO}_{2}$ and $\mathrm{TiO}_{2}$ nanoparticles. J. Environ. Health Sci. Eng. 12, 101121.

Bozzi A., Yuranova T., Kiwi J. 2005. Self-cleaning of wool-polyamide and polyester textiles by $\mathrm{TiO}_{2}$-rutile modification under daylight irradiation at ambient temperature. J. Photochem. Photobiol. A 172, 27-34.

Cai Y., Strømme M., Welch K. 2013. Photocatalytic antibacterial effects are maintained on resin-based $\mathrm{TiO}_{2}$ nanocomposites after cessation of UV irradiation. PLoS ONE 8, e75929.

Cârcel R.A. 2011. Metal oxide photocatalysts for the treatment of wastewaters resulted in the textile industry. PhD thesis. Transilvania University of Braşov, Brașov, Romania.

Carp O., Huisman C.L., Reller A. 2004. Photoinduced reactivity of titanium dioxide. Prog. Solid State Chem. 32, 33-177.

Castellote M., Bengtsson N. 2011. Principles of $\mathrm{TiO}_{2}$ photocatalysis. In: Application of Titanium Dioxide Photocatalysis to Construction Materials. Ohama Y., Van Gemert D. (Eds.), Dordrecht: Springer Netherlands, 5-10.

Chen J., Poon C. 2009. Photocatalytic construction and building materials: From fundamentals to applications. Build. Environ. 44, 1899-1906.

Chen X., Li C., Grätzel M., Kostecki R., Mao S.S. 2012. Nanomaterials for renewable energy production and storage. Chem. Soc. Rev. 41, 7909-7937.

Chen X., Mao S.S. 2007. Titanium dioxide nanomaterials: Synthesis, properties, modifications, and applications. Chem. Rev. 107, 2891-2959.

Cheng C.L., Sun D.S., Chu W.C., Tseng Y.H., Ho H.C., Wang J.B., Chung P.H., Chen J.H., Tsai P.J., Lin N.T., Yu M.S., Chang H.H. 2009. The effects of the bacterial interaction with visible-light responsive titania photocatalyst on the bactericidal performance. J. Biomed. Sci. 16, 7.

Chiarello G.L., Dozzi M.V., Selli E. 2017. TiO ${ }_{2}$-based materials for photocatalytic hydrogen production. Journal of Energy Chemistry 26, 250-258.
Costerton J.W., Stewart P.S., Greenberg E.P. 1999. Bacterial biofilms: a common cause of persistent infections. Science 284, 1318-1322.

Dankovic D., Kuempel E., Wheeler M. 2007. An approach to risk assessment for $\mathrm{TiO}_{2}$. Inhal. Toxicol. 19, 205-212.

Dastjerdi R., Montazer M. 2010. A review on the application of inorganic nano-structured materials in the modification of textiles: Focus on anti-microbial properties. Colloids Surf. B: Biointerfaces 79, 5-18.

Davis D.C., Wilkerson J.W., Zhu J., Hadjiev V.G. 2011. A strategy for improving mechanical properties of a fiber reinforced epoxy composite using functionalized carbon nanotubes. Compos. Sci. Technol. 71, 10891097.

Dholam R., Patel N., Adami M., Miotello A. 2009. Hydrogen production by photocatalytic water-splitting using $\mathrm{Cr}$ - or Fe-doped $\mathrm{TiO}_{2}$ composite thin films photocatalyst. Int. J. Hydrog. Energy 34, 5337-5346.

Dong H., Zeng G., Tang L., Fan C., Zhang C., He X., He Y. 2015. An overview on limitations of $\mathrm{TiO}_{2}$-based particles for photocatalytic degradation of organic pollutants and the corresponding countermeasures. Water Res. 79, 128-146.

EU Directive, 2011. Directive 2011/696/EU of the European Parliament and of the Council of 18 October 2011 as regards the Comission recommendation on the definition of nanomaterial. Off. J. Eur. Union L275, 38-40.

EU Directive, 2013. Directive 2013/39/EU of the European Parliament and of the Council of 12 August 2013 amending Directives 2000/60/EC and 2008/105/EC as regards priority substances in the field of water policy. Off. J. Eur. Union L226, 1-17.

Farzadkia M., Bazrafshan E., Esrafili A., Yang J.K., Shirzad-Siboni M. 2015. Photocatalytic degradation of metronidazole with illuminated $\mathrm{TiO}_{2}$ nanoparticles. J. Environ. Health Sci. Eng. 13, 35-43.

FDA 2002. Listing of color additives exempt from certification. In: Code of Federal Regulations Title 21Food and Drugs. 21 CFR 73.2575. Washington, DC: US Government Printing Office.

Fujishima A., Honda K. 1972. Electrochemical photolysis of water at a semiconductor electrode. Nature 238, 37-38.

Fujishima A., Honda K., Kikuchi S. 1969. Photosensitized electrolytic oxidation on semiconducting n-type $\mathrm{TiO}_{2}$ electrode. Kogyo Kagaku Zasshi 72, 108-113 [in Japanese].

Fujishima A., Zhang X., Tryk D.A. 2007. Heterogeneous photocatalysis: From water photolysis to applications in environmental cleanup. Int. J. Hydrog. Energy 32, 2664-2672.

Gallus M., Akylas V., Barmpas F., Beeldens A., Boonen E., Boréave A., Cazaunau M., Chen H., Daële V., Doussin J.F., Dupart Y., Gaimoz C., George C., Grosselin B., Herrmann H., Ifang S., Kurtenbach R., Maille M., Mellouki A., Miet K., Mothes F., 
Moussiopoulos N., Poulain L., Rabe R., Zapf P., Kleffmann J. 2015. Photocatalytic de-pollution in the Leopold II tunnel in Brussels: NOx abatement results. Build. Environ. 84, 125-133.

Ganesh V.A., Raut H.K., Nair A.S., Ramakrishna S. 2011. A review on self-cleaning coatings. J. Mater. Chem. 21, 16304-16322.

Gorensek M., Recelj P. 2007. Nanosilver functionalized cotton fabric. Text. Res. J. 77, 138-141.

Gupta K., Singh R.P., Pandey A., Pandey A. 2013. Photocatalytic antibacterial performance of $\mathrm{TiO}_{2}$ and Ag-doped $\mathrm{TiO}_{2}$ against $S$. aureus, $P$. aeruginosa and E. coli. Beilstein J. Nanotechnol. 4, 345-351.

Gupta S.M., Tripathi M. 2011. A review of $\mathrm{TiO}_{2}$ nanoparticles. Chinese Sci. Bull. 56, 1639-1657.

Gurr J.R., Wang A.S.S., Chen C.H., Jan, K.Y. 2005. Ultrafine titanium dioxide particles in the absence of photoactivation can induce oxidative damage to human bronchial epithelial cells. Toxicology 213, 6673.

Hamal D.B., Haggstrom J.a, Marchin G.L., Ikenberry M.a, Hohn K., Klabunde K.J.. 2010. A multifunctional biocide/sporocide and photocatalyst based on titanium dioxide $\left(\mathrm{TiO}_{2}\right)$ codoped with silver, carbon, and sulfur. Langmuir 26, 2805-2810.

Hashimoto K., Irie H., Fujishima A. 2005. $\mathrm{TiO}_{2}$ photocatalysis: a historical overview and future prospects. Jpn. J. Appl. Phys. 44, 8269-8285.

Heravi F., Ramezani M., Poosti M., Hosseini M., Shajiei A., Ahrari F. 2013. In vitro cytotoxicity assessment of an orthodontic composite containing titanium-dioxide nano-particles. J. Dent. Res. Dent. Clin. Dent. Prospects 7, 192-199.

Høgsberg T., Loeschner K., Löf D., Serup J. 2011. Tattoo inks in general usage contain nanoparticles. $B r . J$. Dermatol. 165, 1210-1218.

Huang Y., Lenaghan S.C., Xia L., Burris J.N., Stewart C.N.Jr, Zhang M. 2013. Characterization of physicochemical properties of ivy nanoparticles for cosmetic application. J. Nanobiotechnology 11, 3-15.

Jesus M.A., Silva J.T., Timò G., Paiva P.R.P., Dantas M.S., Ferreira A.M. 2015. Superhydrophilic selfcleaning surfaces based on $\mathrm{TiO}_{2}$ and $\mathrm{TiO}_{2} / \mathrm{SiO}_{2}$ composite films for photovoltaic module cover glass. Appl. Adhes. Sci. 3, 5-14.

Jin L., Kuo C., Suib S.L. 2013. Heterogeneous catalysts for biomass conversion. In: New and future developments in catalysis. Suib S.L. (ed.), Elsevier B.V., 253-270.

Kaihong Q., Xin J.H., Daoud W.A. 2007. Functionalizing polyester fiber with a self cleaning property using anatase $\mathrm{TiO}_{2}$ and low-temperature plasma treatment. Int. J. Appl. Ceram. Technol. 4, 554-563.

Karst D., Yang Y. 2006. Potential advantages and risks of nanotechnology for textiles. AATCC Review 6, 44-48.

Kato S., Masuo F. 1964. Titanium dioxidephotocatalyzed liquid phase oxidation of tetralin. Kogyo Kagaku Zasshi 67, 42-50.
Kuhn A., Amandi R., Garcìa-Alvarado F. 2001. Electrochemical lithium insertion in $\mathrm{TiO}_{2}$ with the ramsdellite structure. J. Power Sources 92, 221-227.

Lai Y., Huang J., Cui Z., Ge M., Zhang K.Q., Chen Z., Chi L. 2016. Recent advances in $\mathrm{TiO}_{2}$-based nanostructured surfaces with controllable wettability and adhesion. Small 12, 2203-2224.

Lam Y.L., Kan C.W., Yuen C.W.M. 2010. Effect of concentration of titanium dioxide acting as catalyst or co-catalyst on the wrinkle-resistant finishing of cotton fabric. Fiber. Polym. 11, 551-558.

Lazar M.A., Varghese S., Nair S.S. 2012. Photocatalytic water treatment by titanium dioxide: recent updates. Catalysts 2, 572-601.

Le Guyader L., Chen C. 2012. Characterization of $\mathrm{TiO}_{2}$ nanoparticles cytotoxicity. In: Controlled Nanofabrication: Advances and Applications, Ru-Shi, L. (ed.), Singapore, Pan Stanford Publishing Pte. Ltd., 103-154.

Le T.S., Dao T.H., Nguyen D.C., Nguyen H.C., Balikhin I.L. 2015. Air purification equipment combining a filter coated by silver nanoparticles with a nano- $\mathrm{TiO}_{2}$ photocatalyst for use in hospitals. Adv. Nat. Sci.: Nanosci. Nanotechnol. 6, 015016.

Lee H.J., Kim J., Park C.H. 2014. Fabrication of selfcleaning textiles by $\mathrm{TiO}_{2}$-carbon nanotube treatment. Text. Res. J. 84, 267-278.

Lee H.U., Lee C.S., Lee Y.C., Son B., Park S.Y., Lee J.W., Oh Y.K., Kim Y., Choi S., Lee Y.S., Lee J. 2014. Innovative three-dimensional (3D) eco- $\mathrm{TiO}_{2}$ photocatalysts for practical environmental and biomedical applications. Sci. Rep. 4, 6740-6748.

Lévy M.. 1825. An account of a new mineral. Ann. Philos. 9, 140-142.

Li G., Liu H., Li T.D., Wang J. 2012. Surface modification and functionalization of silk fibroin fibers/fabric toward high performance applications. Mater. Sci. Eng. C 32, 627-636.

Li G., Nie X., Chen J., Jiang Q., An T., Wong P.K., Zhang H., Zhao H., Yamashita H. 2015. Enhanced visible-light-driven photocatalytic inactivation of Escherichia coli using $\mathrm{g} \quad \mathrm{C}_{3} \mathrm{~N}_{4} / \mathrm{TiO}_{2}$ hybrid photocatalyst synthesized using a hydrothermalcalcination approach. Water Res. 15, 343-354.

Limmongkon Y., Johns J., Charerntanyarak L. 2013. Preparation of a $\mathrm{TiO}_{2}$-coated photocatalytic air filter for use with an electrostatic air filter pack for xylene removal. ScienceAsia 39, 284-293.

Limmongkon Y., Sribenjalux P., Chuaybamroong T. 2009. Capability of electrostatic-filter air purifier on airborne microorganism removal. J. Med. Tech. Phys. Ther. 21, 246-256.

Malhi G.S. 2012. The chronic toxicity of titanium dioxide nanoparticles to the freshwater amphipod Hyalella azteca. PhD thesis, Wilfrid Laurier University, Ontario, Canada.

Martínez-Huitle C.A., Rodrigo M.A., Sirés I., Scialdone O. 2015. Single and coupled electrochemical 
processes and reactors for the abatement of organic water pollutants: a critical review. Chem. Rev. 115, 13362-13407.

Matsunaga T., Tomoda R., Nakajima T., Wake H. 1985. Photoelectrochemical sterilization of microbial cells by semiconductor powders. FEMS Microbiol. Lett. 29, 211-214.

Mihailović D., Šaponjić Z., Radoičić M., Lazović S., Baily C.J., Jovančić P., Nedeljković J., Radetić M. 2011. Functionalization of cotton fabrics with corona/air RF plasma and colloidal $\mathrm{TiO}_{2}$ nanoparticles. Cellulose 18, 811-825.

Mills A., Lepre A., Elliott N., Bhopal S., Parkin I.P., O'Neill S.A. 2003. Characterisation of the photocatalyst Pilkington Activ $^{\mathrm{TM}}$ : a reference film photocatalyst? J. Photochem. Photobiol. A 160, 213 224.

Mondal S., Hu J.L. 2006. A novel approach to excellent UV protecting cotton fabric with functionalized MWNT containing water vapor permeable PU coating. J. Appl. Polym. Sci. 103, 3370-3376.

Morales-Torres S., Pastrana- Martínez L.M. 2014. Nanostructured carbon- $\mathrm{TiO}_{2}$ photocatalysts for water purification: an overview. Bol. Grupo Espanol Carbon 32, 9-15.

Ni M., Leung M.K.H., Leung D.Y.C., Sumathy K. 2007. A review and recent developments in photocatalytic water-splitting using $\mathrm{TiO}_{2}$ for hydrogen production. $J$. Renew. Sustain. Energy 11, 401-425.

Nica I.C., Stan M.S., Dinischiotu A., Popa M., Chifiriuc M.C., Lazar V., Pircalabioru G.G., Bezirtzoglou E., Iordache O.G., Varzaru E., Dumitrescu I., Feder M., Vasiliu F., Mercioniu I., Diamandescu L. 2016. Innovative self-cleaning and biocompatible polyester textiles nano-decorated with $\mathrm{Fe}-\mathrm{N}$-doped titanium dioxide. Nanomaterials 6, 214.

Nickheslat A., Amin M.M., Izanloo H., Fatehizadeh A., Mousavi S.M. 2013. Phenol photocatalytic degradation by advanced oxidation process under ultraviolet radiation using titanium dioxide. $J$. Environ. Public Health 23, 1-10.

NIOSH 2011. Occupational Exposure to Titanium Dioxide. In: Current Intelligence Bulletin 63. Cincinnati: National Institute for Occupational Safety and Health.

Nischk M., Mazierski P., Gazda M., Zaleska A. 2014. Ordered $\mathrm{TiO}_{2}$ nanotubes: The effect of preparation parameters on the photocatalytic activity in air purification process. Appl. Catal. B: Environmental 144, 674-685.

Norambuena G., Patel R., Karau M., Wyles C., Jannetto P., Bennet K., Hanssen A., Sierra R. 2016. Antibacterial and biocompatible titanium-copper oxide coating may be a potential strategy to reduce periprosthetic infection: An in vitro study. Clin. Orthop. Relat. Res. 475, 722-732.
O'Neil M.J. 2013. The Merck Index - An Encyclopedia of Chemicals, Drugs, and Biologicals. Cambridge, UK: Royal Society of Chemistry, 1755.

Pakdel E., Daoud W.A., Afrin T., Sun L., Wang X. 2015. Self-cleaning wool: effect of noble metals and silica on visible-light-induced functionalities of nano $\mathrm{TiO}_{2}$ colloid. J. TEXT. I. 106, 1348-1361.

Pasqui D., Barbucci R. 2014. Synthesis, characterization and self cleaning properties of titania nanoparticles grafted on polyester fabrics. J. Photochem. Photobiol. A 274, 1-6.

Patel A., Prajapati P., Boghra R. 2011. Overview on application of nanoparticles in cosmetics. Asian $J$. Pharm. Clin. Res. 1, 40-55.

Pérez-Flores J.C., Baehtz C., Kuhn A., Garcìa-Alvarado F. 2014. Hollandite-type $\mathrm{TiO}_{2}$ : a new negative electrode material for sodium-ion batteries. J. Mater. Chem. A 2, 1825-1833.

Poosti M., Ramazanzadeh B., Zebarjad M., Javadzadeh P., Naderinasab M., Shakeri M.T. 2012. Shear bond strength and antibacterial effects of orthodontic composite containing $\mathrm{TiO}_{2}$ nanoparticles. Eur $J$ Orthod. 35, 676-679.

Ribeiro A.R., Nunes O.C., Fereira M.F.R., Silva A.M.T. 2015. An overview on the advanced oxidation processes applied for the treatment of water pollutants defined in the recently launched Directive 2013/39/EU. Environ. Int. 75, 33-51.

Senzui M., Tamura T., Miura K., Ikarashi Y., Watanabe Y., Fuji M. 2010. Study on penetration of titanium dioxide $\left(\mathrm{TiO}_{2}\right)$ nanoparticles into intact and damaged skin in vitro. J. Toxicol. Sci. 35, 107-113.

Shi H., Magaye R., Castranova V., Zhao J. 2013. Titanium dioxide nanoparticles: a review of current toxicological data. Part. Fibre Toxicol. 10, 15-48.

Shimohigoshi M., Saeki Y. 2007. Research and applications of photocatalyst tiles. In: International RILEM Symposium on Photocatalysis, Environment and Construction Materials - TDP, P. Baglioni, L. Casssar (Eds.), RILEM Publications SARL, 291-297.

Singh A.K. 2015. Engineered nanoparticles: structure, properties and mechanisms of toxicity. Elsevier Inc.

Smijs T.G., Pavel S. 2011. Titanium dioxide and zinc oxide nanoparticles in sunscreens: focus on their safety and effectiveness. Nanotechnol. Sci. Appl. 4, 95-112.

Spencer L.J. 1911. Anatase. In: Encyclopædia Britannica (11th ed.) Cambridge, UK, Cambridge University Press, 919.

Stan M.S., Nica I.C., Dinischiotu A.,Varzaru E., Iordache O.G., Dumitrescu I., Popa M., Chifiriuc M.C., Pircalabioru G.G., Lazar V., Bezirtzoglou E., Feder M., Diamandescu L. 2016. Photocatalytic, antimicrobial and biocompatibility features of cotton knit coated with $\mathrm{Fe}-\mathrm{N}$-doped titanium dioxide nanoparticles. Materials 9, 789. 
Sunada K., Watanabe T., Hashimoto K. 2003. Studies on photokilling of bacteria on $\mathrm{TiO}_{2}$ thin film. $J$. Photochem. Photobiol. A. 156, 227-233.

Tang B., Wang J., Xu S., Afrin T., Xu W., Sun L., Wang X. 2011. Application of anisotropic silver nanoparticles: Multifunctionalization of wool fabric. J. Colloid Interface Sci. 356, 513-518.

Thompson T.L., Yates Jr J.T. 2006. Surface science studies of the photoactivation of $\mathrm{TiO}_{2}$-new photochemical processes. Chem. Rev. 106, 44284453.

Thunyasirinon C., Sribenjalux P., Supothina S., Chuaybamroong P. 2015. Enhancement of air filter with $\mathrm{TiO}_{2}$ photocatalysis for Mycobacterium tuberculosis removal. AEROSOL AIR QUAL. RES. 15, 600-610.

Tricoli A., Righettoni M., Pratsinis S.E. 2009. Rapid synthesis of anti-fogging coatings. NSTI-Nanotech 3, 192-193.

Tryba B. 2008. Increase of the photocatalytic activity of $\mathrm{TiO}_{2}$ by carbon and ron modifications. Int. J. Photoenergy 2008, ID 721824, doi:10.1155/2008/721824

Vasilev K., Cook J., Griesser H.J. 2009. Antibacterial surfaces for biomedical devices. Expert Rev. Med. Devices 6, 553-567.

Verdier T., Coutand M., Bertron A., Roques C. 2014. Antibacterial activity of $\mathrm{TiO}_{2}$ photocatalyst alone or in coatings on $E$. coli: the influence of methodological aspects. Coatings 4, 670-686.

Veronovski N., Rudolf A., Smole M.S., Kreze T., Gersak J. 2009. Self-cleaning and handle properties of $\mathrm{TiO}_{2-}$ modified textiles. Fiber. Polym.10, 551-556.

Visai L., Nardo L., Punta C., Melone L., Cigada A., Imbriani M., Arciola C.R. 2011. Titanium oxide antibacterial surfaces in biomedical devices. Int. J. Artif. Organs 34, 929-946.

Wang J., Fan Y. 2014. Lung injury induced by $\mathrm{TiO}_{2}$ nanoparticles depends on their structural features: size, shape, crystal phases, and surface coating. Int. J. Mol. Sci. 15, 22258-22278.

Wang W., Huang G., Yu J.C., Wong P.K. 2015. Advances in photocatalytic disinfection of bacteria: Development of photocatalysts and mechanisms. $J$. Environ. Sci. 1, 232-247.

Weast R.C. 1988-1989. Handbook of Chemistry and Physics (69th ed.) Boca Raton, FL: CRC Press Inc., B-140.

Wenzel S.M., Welzel J., Hafner C., Landthaler M., Bäumler W. 2010. Permanent make-up colorants may cause severe skin reactions. Contact Dermatitis 63, 223-227.

Weon S., Choi J., Park T., Choi W. 2017. Freestanding doubly open-ended $\mathrm{TiO}_{2}$ nanotubes for efficient photocatalytic degradation of volatile organic compounds. Appl. Catal. B. 205, 386-392.
Wu B., Huang R., Sahu M., Feng X., Biswas P., Tang Y.J. 2010. Bacterial responses to $\mathrm{Cu}$-doped $\mathrm{TiO}(2)$ nanoparticles. Sci. Total Environ. 408, 1755-1758.

$\mathrm{Wu} \mathrm{Y.,} \mathrm{Xu} \mathrm{B.} \mathrm{2005.} \mathrm{Synthesis} \mathrm{and} \mathrm{characterization} \mathrm{of}$ monoclinic $\mathrm{TiO}_{2}$ nanosheets. Chin. Sci. Bull. 50, 2153-2156.

Xia Y., Zhu K., Kaspar T.C., Du Y., Birmingham B., Park K.T., Zhang Z. 2013. Atomic structure of the anatase $\mathrm{TiO}_{2}(001)$ surface. J. Phys. Chem. Lett. 4, 2958-2963.

Xiang Q., Yu J., Jaroniec M. 2012. Synergetic effect of MoS2 and graphene as cocatalysts for enhanced photocatalytic $\mathrm{H}_{2}$ production activity of $\mathrm{TiO}_{2}$ nanoparticles. J. Am. Chem. Soc. 134, 6575-6578.

Yadav H.M., Kim J.S., Pawar S.H. 2016. Developments in photocatalytic antibacterial activity of nano $\mathrm{TiO}_{2}$ : A review. Korean J. Chem. Eng. 33, 1989-1998.

Yamamoto M., Nishikawa N., Mayama H., Nonomura Y., Yokojima S., Nakamura S., Uchida K. 2015. Theoretical explanation of the lotus effect: superhydrophobic property changes by removal of nanostructures from the surface of a lotus leaf. Langmuir 31, 7355-7363.

Yoong L.S., Chong F.K., Dutta B.K. 2009. Development of copper-doped $\mathrm{TiO}_{2}$ photocatalyst for hydrogen production under visible light. Energy 34, 1652-1661.

Yu J., Qi L., Jaroniec M. 2010. Hydrogen production by photocatalytic water splitting over $\mathrm{Pt} / \mathrm{TiO}_{2}$ nanosheets with exposed (001) facets. J. Phys. Chem. C 114, 13118-13125.

Yuan Y., Ding J., Xu J., Deng J., Guo J. 2010. $\mathrm{TiO}_{2}$ nanoparticles co-doped with silver and nitrogen for antibacterial application. J. Nanosci. Nanotechnol. 10, 4868-4874.

Zhu T., Gao S.P. 2014. The stability, electronic structure, and optical property of $\mathrm{TiO}_{2}$ polymorphs. J. Phys. Chem. C 118, 11385-11396. 